\title{
Perceptions on Population Decline and Ethno-cultural Knowledge of Hooded Vulture (Necrosyrtes monachus) in Southwest States of Nigeria.
}

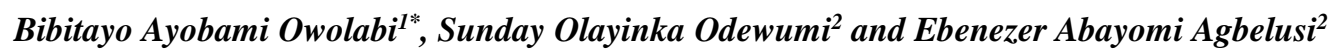

${ }^{1}$ Department of Wildlife and Ecotourism Management, Faculty of Renewable Natural Resources Management. College of Agriculture, Osun State University, Osogbo. Osun State, Nigeria.

${ }^{2}$ Department of Ecotourism and Wildlife Management, Federal University of Technology, Akure, Ondo State, Nigeria

*Corresponding author: bibitayo.owolabi@uniosun.edu.ng

http://dx.doi.org/10.4314/vulnew.v78i1.2

\begin{abstract}
The global decline of many vulture populations due to anthropogenic activities is increasing and is largely connected to cases of poisoning. The objectives of this study were to access local perceptions and knowledge of vulture declines, and to determine the ethno-cultural uses of vulture body parts across southwest Nigeria. Semi-structured questionnaires were administered through interviews with randomly selected respondents $(n=144)$ between August 2018 and July 2019. Results showed that 82.5\% $(n=$ $119)$ of respondents confirmed the sharp decline in vulture populations. $79.8 \%(n=115)$ of respondents considered poisoning to be the cause of vulture deaths in the study area and $79.8 \%(n=117)$ confirmed the need to conserve the remaining vultures. $80.5 \%(n=116)$ of respondents reported that vultures play a key role in Yoruba traditional settings. Vulture parts (organs) were reported as being important in ethno-cultural traditional benefits ranging from curing ailments, to making financial fortune to enhancing dreams, having visions about the future, healing and magic use. Conservation education and public awareness to shift the public mindset away from the use of vultures for rituals and healing purposes and the resultant negative effect of extirpation and extinction is the only way forward.
\end{abstract}

\section{Introduction}

Vultures provide essential ecosystem services, yet are among the most threatened groups of birds worldwide (Ogada, et al. 2012). Recent studies have revealed that vulture populations have declined, particularly in Africa (Virani et al. 2011, Ogada et al. 2012, Murn et al. 2016, Ogada et al. 2016). The vulture decline crisis has gained the attention of conservationists and resulted in published reports that have the objective of developing a common strategy to save vultures from extinction (Botha et al. 2012; Ogada et al. 2015a).

The International Union of Conservation of Nature (IUCN) reports that $69 \%$ of vultures and condors are listed as Threatened, Near Threatened, Endangered or Critically Endangered (BirdLife International 2013). The Hooded Vulture (Necrosyrtes monachus) is among the species listed as critically endangered, due to significant population declines; poisoning and habitat degradation have been reported as the major drivers of these declines (Virani et al. 2011, Ogada et al. 2012, Ogada et al. 2016).

The Hooded Vulture has established a close and commensal relationship with human habitations in West Africa. These habitations include livestock farming areas, slaughter houses and rubbish dump sites in highly urbanised areas (Gangoso et al. 2013; O’Neal Campbell 2016). This relationship with human habitations has 
exposed the Hooded Vulture to risks and persecution. Despite the ongoing global discussions and huge awareness about declining populations of vulture species across globe, in Nigeria, the Hooded Vulture is still considered the most useful of all wildlife for the treatment of a range of physical and mental diseases (Ejidike et al. 2013).

However, there is still little known or reported about the understanding and perceptions of local people towards declines of Hooded Vultures and the ethno-cultural significance of this species in Nigeria. Therefore, the objectives of this study are to access people's perceptions and knowledge of vulture declines and to determine the ethnocultural uses of vulture body parts across southwest Nigeria.

\section{Materials and Methods.}

\section{Study Area.}

The study took place in the southwestern region of Nigeria. The region is the home to the Yoruba speaking tribe of Nigeria and it consists of six (6) states namely: Lagos, Ogun, Oyo, Osun, Ondo and Ekiti states. The area lies between longitudes $\mathrm{E} 2^{\circ} 31^{\prime}-$ and $6^{\circ} 00^{\prime}$ and latitudes $\mathrm{N} 6^{\circ} 21^{\prime}-8^{\circ} 37^{\prime}$ and covers a land area of $77,818 \mathrm{~km}^{2}$. The study area is bounded in the East by Edo and Delta states, in the North by Kwara and Kogi states, in the West by the Republic of Benin and in the south by the Gulf of Guinea (Figure 1).

The climate of southwestern Nigeria is tropical and characterized by wet (May-September) and dry (October-April) seasons.

\section{Human Population of the Study Area.}

The National Population Census (2006) put the approximate population of southwest Nigeria at 27.7 million. Lagos has the highest population with 9.2 million people, followed by Oyo with 5.6 million, Ogun state with 4 million, Ondo state and Osun State with 3.5 million, while Ekiti had the lowest with an approximate population of 2.4 million people.

\section{Sampling method}

Data on the perceptions, local knowledge and traditional uses of Hooded Vulture in southwest Nigeria were collected from wildlife traders, hunters, farmers and herbalist using semistructured interviews conducted between August 2018 and July 2019. A purposive sampling method by (Babbie 2001) was adopted, and respondents with multiple years of experience in the wildlife trade and hunting were the main focus of the study.

Data on local perceptions of vulture conservation were collected from 144 respondents chosen across four (4) communities in four of the southwestern states of Nigeria, where Hooded Vulture presence has been established during reconnaissance surveys. The communities are Ado Awaye in Oyo state, Lekki in Lagos state, Oka Akoko in Ondo state, and Ijebu Igbo in Ogun state. The structuring of the questionnaire followed that of Reson (2012), and questions were asked under the following topics: (i) perceptions and knowledge vulture declines and their ecological importance and (ii) the ethno-cultural uses of vulture body parts.

The questions were carefully constructed to be very direct and straightforward in an attempt to avoid bias in answering (Kasunic 2005).

The questionnaire was pre-tested among selected wildlife conservation practitioners, and where necessary, questions were reframed for clarity. Necessary permission to conduct the study was obtained from the Ministry of Agriculture and the traditional rulers. Wildlife traders, hunters' groups and respondents were informed of the planned interviews one to two days in advance. 


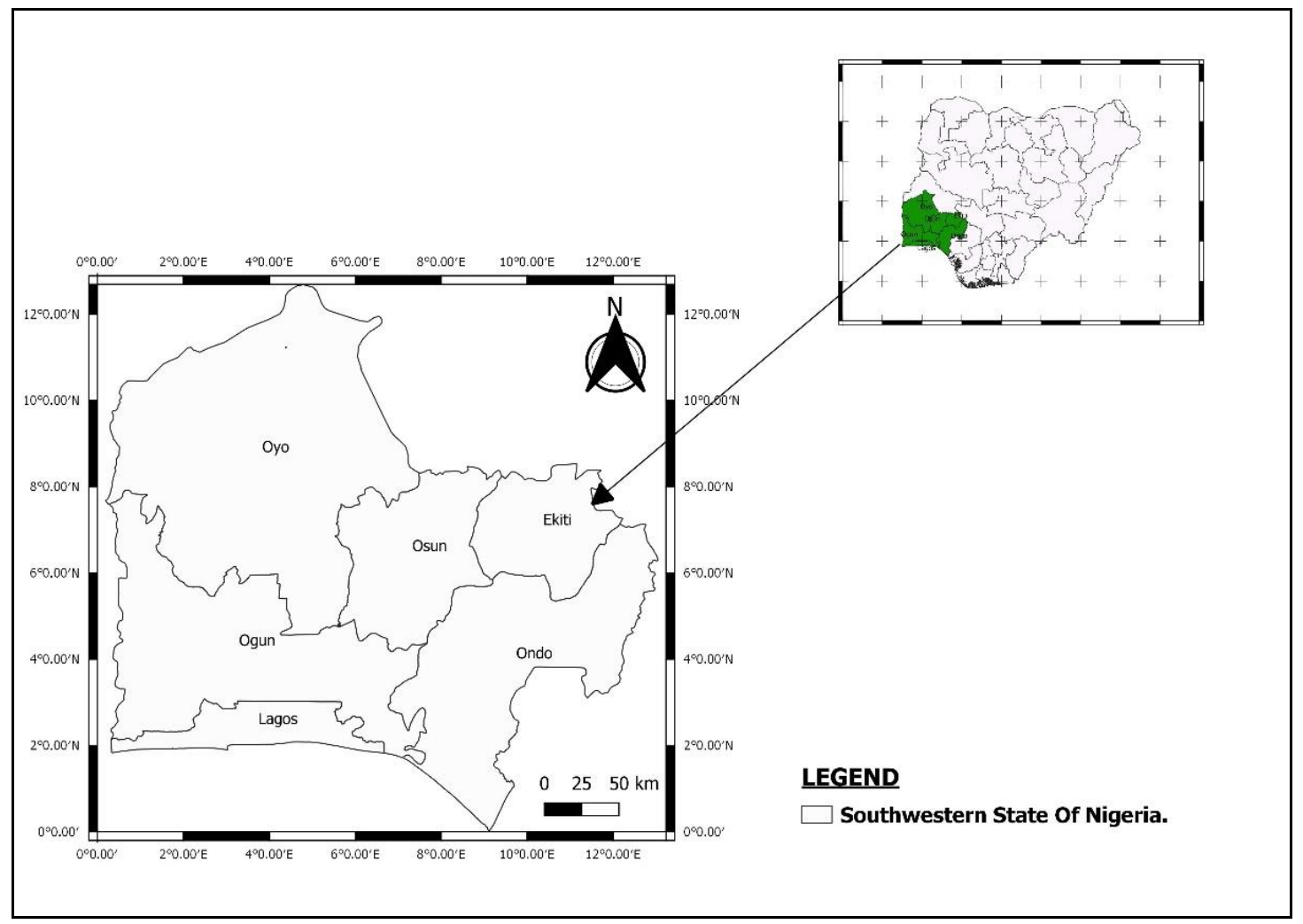

Figure 1: Map of the study area, showing the Southwestern States of Nigeria.

\section{Data collection and analyses.}

Interviews were conducted in Yoruba, which is the most widely spoken language in the study area. All interviewed participants were fluent Yoruba speakers. Interviews took place at each respondent's home and lasted for about 20 minutes once an individual was ready and willing to be interviewed. Anonymity of responses was ensured by only using voice recording during each interview. Questions were open-ended to get more information and to understand people's perceptions in a way that was not preconceived (Gandiwa et al. 2013).

\section{Results}

\section{Perceptions and understanding of vulture declines.}

The sample on perception and understanding of vulture declines comprised 63\% $(n=90)$ males and $37 \%(n=54)$ females. $56 \%(n=80)$ of the respondents were head of their household and indicated the vulture trade as a means of livelihood. $53 \%(n=77)$ of respondents claimed to have been in the trade of selling and using Hooded Vulture parts for more than six years (Table 1).

About $80 \%$ of the 115 -respondent believed that poisoned carcasses of animals lead to the death of vulture in the study area, with $86 \%(n=124)$ reporting that intentional poisoning and habitat loss is a major factor in the decline.

$80.5 \%(n=116)$ of the respondents confirmed the role of vultures in Yoruba tradition, with $88.7 \%(n=128)$ of the respondent claiming that conservation education would be an appropriate step to its conservation. $82 \%(n=111)$ of respondents would be willing to participate in conservation awareness on the need to conserve the Hooded Vulture (Table 2). 
Table 1: Socio-economic and demographic profiles of participants across four communities in southwest Nigeria.

\begin{tabular}{|c|c|c|c|c|c|}
\hline \multirow[t]{2}{*}{ Variables } & \multicolumn{4}{|c|}{ Study Area } & \multirow{2}{*}{$\begin{array}{l}\text { Total } \\
\text { N }(\%)\end{array}$} \\
\hline & Ado Awaye N (\%) & Oka Akoko N (\%) & Lekki N (\%) & Ijebu Igbo N (\%) & \\
\hline \multicolumn{6}{|l|}{ Gender } \\
\hline Female & $11(31)$ & $15(42)$ & $14(39)$ & $14(39)$ & $54(37)$ \\
\hline Male & $25(69)$ & $21(58)$ & $22(61)$ & $22(61)$ & $90(63)$ \\
\hline \multicolumn{6}{|l|}{ Age } \\
\hline $18-25$ & $8(22)$ & $13(36)$ & $9(25)$ & $11(31)$ & $41(28)$ \\
\hline $26-50$ & $23(64)$ & $19(53)$ & $25(69)$ & $22(61)$ & $89(62)$ \\
\hline $51+$ & $5(14)$ & $4(11)$ & $2(6)$ & $3(8)$ & $14(10)$ \\
\hline \multicolumn{6}{|c|}{ Level of education } \\
\hline None & $3(9)$ & $1(3)$ & 0 & $2(6)$ & $6(4)$ \\
\hline Primary & $16(46)$ & $20(55)$ & $5(14)$ & $17(47)$ & $58(41)$ \\
\hline Secondary & $12(34)$ & $9(25)$ & $26(72)$ & $10(28)$ & $57(40)$ \\
\hline Tertiary & $4(11)$ & $6(17)$ & $5(14)$ & $7(19)$ & $22(15)$ \\
\hline \multicolumn{6}{|l|}{ Religion } \\
\hline Christian & $15(42)$ & $13(36)$ & $16(44)$ & $8(22)$ & $52(43)$ \\
\hline Africa tradition & $11(30)$ & $15(42)$ & $10(28)$ & $19(53)$ & $33(27)$ \\
\hline Muslim & $10(28)$ & $8(22)$ & $10(28)$ & $9(25)$ & $37(30)$ \\
\hline None & 0 & 0 & 0 & 0 & 0 \\
\hline \multicolumn{6}{|c|}{ Source of livelihood } \\
\hline Farming & $21(58)$ & $24(68)$ & 0 & $15(41)$ & $60(41)$ \\
\hline Herbalist & $5(14)$ & $9(26)$ & 0 & $6(17)$ & $20(14)$ \\
\hline Wildlife traders & $3(8)$ & 0 & $15(42)$ & $6(17)$ & $24(17)$ \\
\hline Hunter & $7(20)$ & $2(6)$ & $21(58)$ & $9(25)$ & $40(28)$ \\
\hline \multicolumn{6}{|c|}{ Period of residence and trade/use of Hooded Vulture parts. } \\
\hline $0-2$ years & $6(17)$ & $8(22)$ & $4(11)$ & $2(6)$ & $20(14)$ \\
\hline $3-5$ years & $8(22)$ & $10(28)$ & $21(58)$ & $8(22)$ & $47(33)$ \\
\hline $6+$ years & $22(61)$ & $18(50)$ & $11(31)$ & $26(72)$ & $77(53)$ \\
\hline Head of family & $17(47)$ & $23(64)$ & $21(58)$ & $19(53)$ & $80(56)$ \\
\hline
\end{tabular}


Table 2: Perceptions and understanding of vultures and their ecological importance among participants across communities in southwest Nigeria.

\begin{tabular}{|l|l|l|l|l|l|l|}
\hline \multicolumn{2}{|c|}{} & $\begin{array}{l}\text { Ado } \\
\text { Awaye } \\
\text { Akoko }\end{array}$ & $\begin{array}{l}\text { Oka } \\
\text { Percentage of agreement by respondent. }\end{array}$ & Lekki & Ijebu Igbo & Total \\
\hline $\begin{array}{l}\text { Vultures are important in Yoruba tradition and } \\
\text { should be conserved for their ecological role. }\end{array}$ & $34(92)$ & $32(87)$ & $20(56)$ & $31(84)$ & $117(79.8)$ \\
\hline $\begin{array}{l}\text { Spread of diseases is reduced in communities } \\
\text { where vultures thrive. }\end{array}$ & $28(74)$ & $23(64)$ & $16(45)$ & $29(81)$ & $96(66)$ \\
\hline $\begin{array}{l}\text { My household is willing to participate in } \\
\text { vulture conservation awareness programs }\end{array}$ & $35(97)$ & $26(81)$ & $20(67)$ & $30(83)$ & $111(82)$ \\
\hline $\begin{array}{l}\text { Conservation education is key in vulture } \\
\text { conservation }\end{array}$ & $33(92)$ & $30(83)$ & $31(86)$ & $34(94)$ & $128(88.7)$ \\
\hline $\begin{array}{l}\text { Disappearance of vultures in the study area } \\
\text { now as compared to the past years. }\end{array}$ & $28(78)$ & $30(83)$ & $30(83)$ & $31(86)$ & $119(82.5)$ \\
\hline $\begin{array}{l}\text { Poisoned carcasses lead to vulture deaths in the } \\
\text { study area. }\end{array}$ & $31(86)$ & $26(72)$ & $30(83)$ & $28(78)$ & $115(79.8)$ \\
\hline $\begin{array}{l}\text { Intentional poisoning of carcasses to target } \\
\text { vultures is causing population decline in the } \\
\text { study area. }\end{array}$ & $35(97)$ & $28(78)$ & $30(83)$ & $31(86)$ & $124(86)$ \\
\hline
\end{tabular}

Ethno-cultural values of Hooded Vulture body parts in Southwest Nigeria.

The study showed that the brain is the most used part of the Hooded Vulture, it had the highest frequency of use across the study area followed by bones, legs, beak, feather, neck, skull, wings and hearts (Figure 2).

\section{Discussion}

Our study reveals that most respondents are aware of the fast-declining vulture population. Respondents perceived the ecological roles that vultures play in the environment are reducing the spread of diseases through consumption of dead carcasses. This perception is in tandem with the findings of Whelan et al. (2008), who reported that vultures play a significant ecological role as nature's garbage disposers.

Hooded Vultures are a highly persecuted species in the study area and their survival is highly threatened as a result of both deliberate and unintentional poisoning. Hooded Vultures are scavengers and depend solely on carrion, and this food source is deliberately laced with poison by hunters and wildlife traders who pack the dead birds and prepare their body parts for trade. This constant practice in the study area has led to ongoing population declines. 


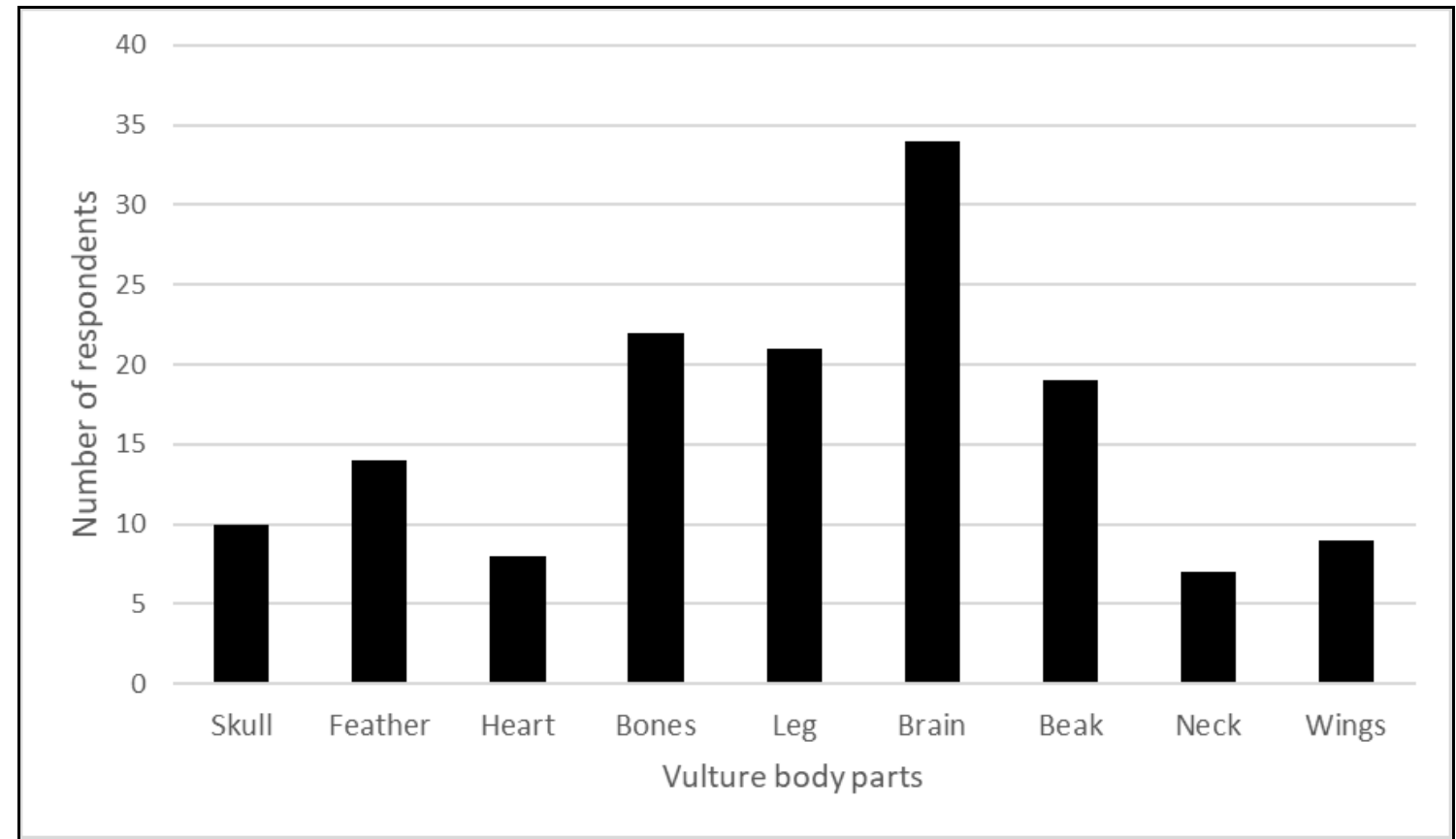

Figure 2: Vulture body parts used for ethno-cultural purposes across communities in southwest Nigeria (144 respondents).

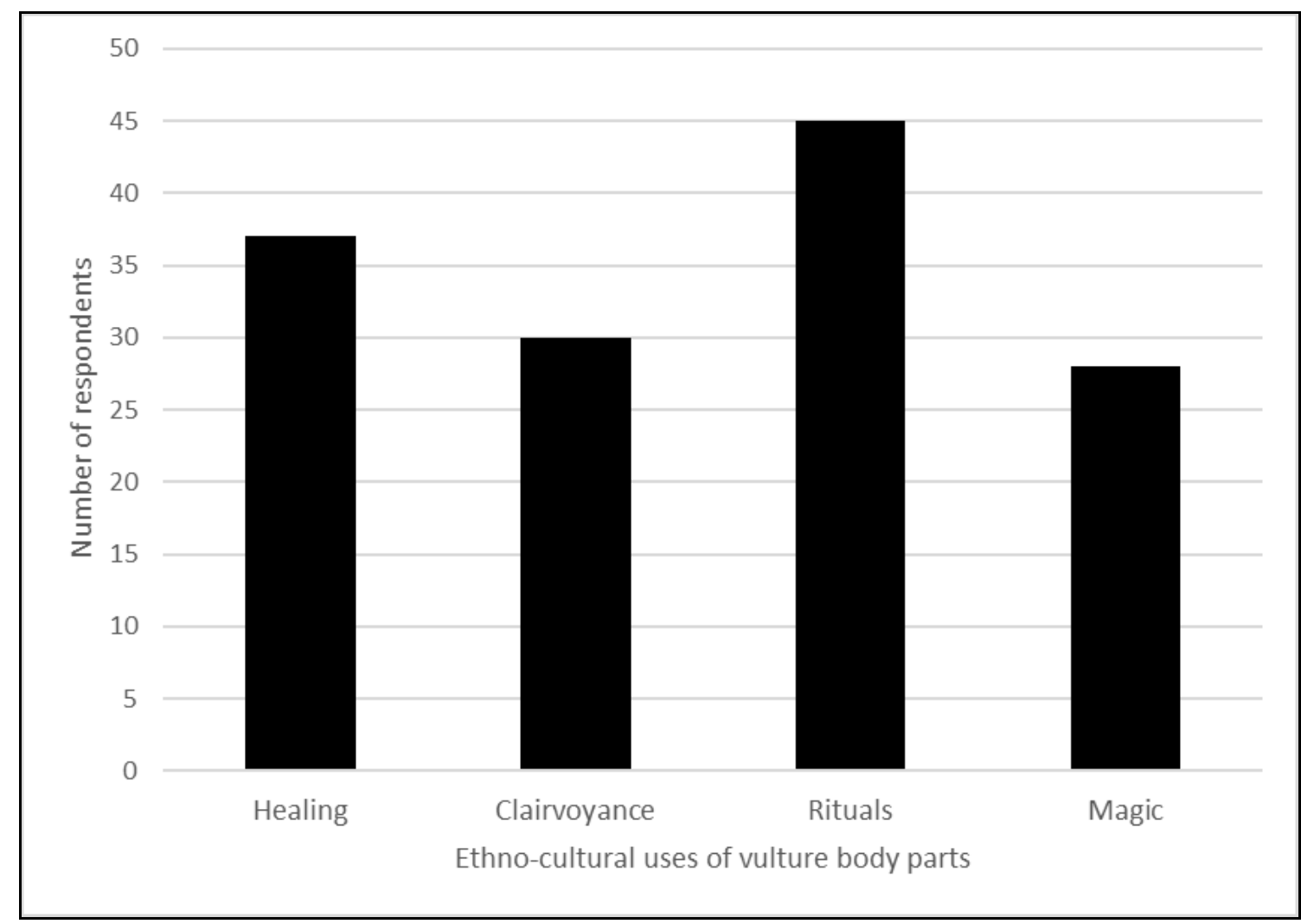

Figure 3: Ethno-cultural uses and Yoruba mythologies associated with Vulture across communities in southwest Nigeria (144 respondents). 
Our study further revealed the high use value of vulture body parts for traditional medicine and other fetish purposes. These findings on the sociocultural uses of Hooded Vulture body parts is similar to studies reported by McKean et al. (2013). Hooded vulture body parts recorded in this study (skull, feather, heart, bones, leg, brain, beak, neck, and wings) were perceived to be useful ingredients in the preparation of concoctions for healing, clairvoyance, rituals and magic for traditionalists. This finding is similar to the findings of Reson (2012).

Preference for Hooded vulture body parts for traditional medicinal purposes in southwest Nigeria is very high. The high value placed on vulture brains and bones in the study highlight the perceived importance attached to these body parts by herbalists, ritualists and herbal practitioners, most especially for healing purpose. These findings also align with that of McKean et al. (2013), where the vulture brain was found to be the most used of all vulture body parts.

The skull, bones and the legs are also used in clairvoyance, which is the belief of seeing into the future or beyond normal sensory contact (Saidu \& Buij 2013, Mullié et al. 2017). The use of the skull as a cure for headaches has been reported by McKean et al. (2013) as well as a support for magic. Feathers are said to be used in securing spiritual protection and power against enemy. These findings partially align with findings of Bobo et al. (2014) in Cameroon, where the feathers are reportedly used as a source of spiritual protection.

The Hooded Vulture is considered a sacred species in some communities across the study area, and its continued presence is of utmost importance owing to the roles it plays in traditional religion activities and cultural beliefs, not forgetting the significant ecological role as nature's garbage disposers. However, the survival and sustained population of Hooded Vulture in natural ecosystems is increasingly being threatened to various degrees by anthropogenic activities. Thus, there is a need for conservation bodies and government authorities to identify, recognise and work closely through the provision of social amenities in local communities to encourage traditional belief systems that support biodiversity conservation most importantly the Hooded Vulture. These partnerships will go a long way in mapping out vulture conservation plans aimed at reducing the cultural use of Hooded Vulture body parts.

Of great importance and significance is the high percentage of respondents who are willing and ready to participate in vulture conservation awareness programmes aimed at enlightening local people about the importance of vultures conservation. This is indeed very encouraging and further improved by the fact that most respondents are educated youths in their active and productive age.

Vultures play a key spiritual and positive role for worshipers of River Oshún in Osun state. The Oshún goddess has a vulture as a symbol and is believed to have once saved the world from draught by flying up to heaven (turning into a vulture in the process).

In Ifa divination, a religion in southwest Nigeria, the Hooded Vulture (Igun in Yoruba) is associated with prospects of growing old. Also, when Hooded Vulture feed on sacrifices, it is a sign that the sacrifice has been acceptable to the gods.

Yoruba mythologies believe strongly in vultures and as a result there are many diabolical interpretations to various vulture parts in preparing herbal concoctions. According to a verse in the Ifa divination: "Ba o ba ri igun, a ko gbodo se'ebo" ("without Vulture, nobody performs sacrifice"). These findings all confirm the report of Moleón et al. (2014) that, from time immemorial, vultures provide important spiritual services. 


\section{Conclusion}

This study focused on perceptions of population decline and ethno-cultural knowledge of Hooded Vultures in the Southwest States of Nigeria. Results from this study shows that people are aware of the vulture population decline and also that the ethno-cultural values attached to Hooded Vulture body parts across the study area are high. Some of these ethno-cultural values are attached to the use of vulture body parts by traditionalists for the treatment of ailments and other fetish purposes. With these varying values in body parts usage, it is evident that the poisoning of Hooded
Vultures is still on the increase. There is an urgent need to proactively educate herbal practitioners and sensitise people who patronise them, to shift their attentions away from the use of vulture body parts for rituals and healing purposes and seek modern medicine as the alternative.

Non-governmental conservation organisations should intensify their efforts in organising conservation education and public awareness on the importance of conservation. Lastly, community participation and involvement in biodiversity conservation should be encouraged to protect community forests.

\section{References}

Babbie, E.R. 2001. The practice of social research (9th edn). Cape Town: Oxford University Press.

BirdLife International 2013: Spotlight on birds as indicators. Presented as part of the BirdLife State of the world's birds website. Available at: http://datazone.birdlife.org/home.

Bobo, K.S., Aghomo, F.F.M., Ntumwel, B.C. 2014. Wildlife use and the role of taboos in the conservation of wildlife around the Nkwende Hills Forest Reserve; south-west Cameroon. Journal of Ethnobiology and Ethnomedicine 11: 2.

Botha, A., Ogada, D.L. \& Virani, M.Z. 2012. Proceedings of the Pan-African Vulture Summit 2012. Pages 1-47. Pan-African Vulture Summit. Masai Mara, Kenya.

Buij, R., Nikolaus, G., Whytock, R., Ingram, D.J. \& Ogada, D. 2015. Trade of threatened Vultures and other raptors for fetish and bushmeat in West and Central Africa. Oryx 50: 606-616.

Ejidike, B.N. \& Ajayi, S.R. 2013. Trends in Wildlife Conservation Practices in Nigeria. International Journal of Biodiversity Conservation 5: 185-191.

Gangoso, L., Agudo, R., Anadon, J.D., De la Riva, M., Suleyman, A.S., Porter, R. \& Donazar, J.A. 2013. Reinventing mutualism between humans and wild fauna: Insights from Vultures as ecosystem services providers. Conservation Letters 6: 172-179.

Gandiwa, E., Heitkonig, I. M., Lokhorst, A. M., Prins, H. H. T. \& Leeuwis, C. 2013. Illegal hunting and law enforcement during a period of economic decline in Zimbabwe: A case study of northern Gonarezhou National Park and adjacent areas. Journal for Nature Conservation 21: 133-142.

IUCN. 2016. The IUCN Red List of Threatened Species. Version 2016-2. Available at http://www.iucnredlist.org/. Accessed on 30 October 2016.

Kasunic, M. 2005. Designing an Effective Survey. Handbook CMU/SEI-2005-HB-004, Software Engineering Institute, Carnegie Mellon University. [Online]. Available at 
www. sei.cmu.edu/pub/documents/05.reports/pdf/05hb004.pdf

McKean, S., Mander, M., Diederichs, N., Ntuli, L., Mavundla, K., Williams, V. \& Wakelin, J. 2013. The impact of traditional use on vultures in South Africa. Vulture News 65: 15-36

Moleón, M., Sánchez-Zapata, J. A., Margalida, A., Carrete, M., Donázar, J. A., \& Owen-Smith, N. 2014. Humans and scavengers: The evolution of interactions and ecosystem services. BioScience 64: 394403

Murn, C., Mundy, P., Virani, M. Z., Borello, W. D., Holloway, G. J. \& Thiollay, J. M. 2016. Using Africa's protected area network to estimate the global population of a threatened and declining species: a case study of the Critically Endangered White-headed Vulture Trigonoceps occipitalis. Ecology and Evolution 6: 1092-1103.

Mullié, W.C., Couzi, F-X., Diop, M.S., Piot, B., Peters, T., Reynaud, P.A. \& Thiollay, J-M. 2017. The decline of an urban Hooded Vulture Necrosyrtes monachus population in Dakar, Senegal, over 50 years. Ostrich 88: 131-138.

Ogada, D. L., Keesing, F. \& Virani, M. Z. 2012. Dropping dead: causes and consequences of vulture population declines worldwide. Annals of the New York Academy of Sciences 1249: 57-71.

Ogada, D., Botha, A. \& Shaw, P. 2016. Ivory poachers and poison: drivers of Africa's declining vulture populations. Oryx 50: 593-596.

O’Neal Campbell M. 2016. Vultures: Their evolution, Ecology and Conservation. Page (O'Neal Campbell M, editor) First. CRC Press - Taylor \& Francis Group, New York.

Reson, E.N.M. 2012. Assessing Maasai attitudes and perceptions toward vultures: A case study of resident Maasai around Maasai Mara National Reserve, Kenya. MSc Thesis, Clemson University, South Carolina.

Saidu, Y. \& Buij, R. 2013. Traditional medicine trade in vulture parts in northern Nigeria. Vulture News 65: 4-14

Thiollay, J.M. 2007. Raptor Population Decline in West Africa. Ostrich, 78: 405-413.

Virani, M.Z., Kendall, C., Njoroge, P. \& Thomsett, S. 2011. Major declines in the abundance of vultures and other scavenging raptors in and around the Masai Mara ecosystem, Kenya. Biological Conservation 144: 746-752.

Whelan, C.J., Wenny, D.G. \& Marquis, R.J. 2008. Ecosystem services provided by birds. Annals of the New York Academy of Sciences 1134: 25-60.

Whytock, R.C., Buij, R., Virani, M.Z. \& Morgan, B.J. 2014. Do large birds experience previously undetected levels of hunting pressure? Oryx 50: 76-83.

$* * * * * *$ 